\title{
Populasi Mikrob di Rizosfer dan Pertumbuhan Caisim (Brassica juncea) di Tanah Dikontaminasi Insektisida Organoklorin setelah Aplikasi Konsorsia Mikrob dan Kompos
}

\author{
Reginawanti Hindersah $^{1^{*)}}$, Wahyuda Rachman ${ }^{2)}$, Betty Natalie Fitriatin ${ }^{1)}$, dan Dedi Nursyamsi ${ }^{3)}$ \\ ${ }^{1)}$ Fakultas Pertanian Universitas Padjadjaran, Sumedang 45363 \\ ${ }^{2)}$ Fakultas Pertanian Universitas Padjadjaran, Sumedang 45363 \\ ${ }^{3}$ Balai Penelitian Lingkungan Pertanian, \\ Jalan Raya Jakenan-Jaken km 5, Jakenan Pati
}

Diterima 11-12-2012 Disetujui 25-11-2013

\begin{abstract}
Organochlorine insecticide hed been banned for agriculture but nowadays its residue was still found in some agricultural soil. One of ways to lower organochlorine residue in soil is by using degrading-organochlorine microbial consortia accompanied by compost application. However, application of exogenous microbes might affect bacterial and fungal population in soil and hence plant growth. The pot experiment has been set up to verify the influence of Pseudomonas mallei and Trichoderma sp. and compost on total bacteria and fungi on rhizosphere of caisim (Brassica juncea L.) grown on Andisols which were contaminated with organochlorine insecticide of Heptachlor, endosulfan, dieldrin, and DDT. Experimental design was Factorial Randomized Block Design with three replicates. The first factor was microbial consortia of P.mallei and Trichoderma sp., and the second one was the kind of compost. The result showed that effect of microbial consortia on total bacteria population was determined by the kind of compost. Total bacterial population in rhizosphere of caisim grown with cow manure compost and microbial consortia was more increased. However, microbial consortia as well as any kind of compost did not influence total fungal population in caisim rhizosphere. Amount of leaf increased due to microbial and compost application however plant yield did not.
\end{abstract}

Keywords: caisim, compost, microbial consortia, organochlorine insecticide

\begin{abstract}
ABSTRAK
Insektisida organoklorin telah dilarang digunakan untuk pertanian tetapi residunya masih dapat ditemukan di beberapa lahan pertanian. Residu organoklorin di tanah dapat diturunkan melalui inokulasi konsorsium mikrob pendegradasi organoklorin yang bersamaan dengan pemberian kompos. Namun, aplikasi mikrob eksogen dapat mempengaruhi populasi bakteri dan fungi di tanah dan selanjutnya pertumbuhan tanaman. Tujuan percobaan pot ini adalah untuk mendapatkan informasi tentang pengaruh Pseudomonas mallei dan Trichoderma sp. serta kompos terhadap populasi bakteri dan fungi di rizosfer caisim (Brassica juncea L.) yang ditanam di tanah dikontaminasi insektisida organoklorin berupa heptaklor, endosulfan, dieldrin dan DDT. Percobaan menggunakan Rancangan Acak Kelompok dengan tiga ulangan. Faktor pertama adalah konsorsia mikrob P.mallei dan Trichoderma sp. dan faktor kedua adalah jenis kompos. Hasil penelitian menunjukkan bahwa pengaruh konsorsia mikroba terhadap populasi bakteri total ditentukan oleh jenis kompos. Populasi bakteri total meningkat di rizosfer caisim yang ditanam dengan kompos kotoran sapi dan konsorsia mikroba. Namun, konsorsia mikrob
\end{abstract}

\footnotetext{
*Telp: +62811221834

Email: reginawanti@unpad.ac.id
} 
maupun jenis kompos tidak mempengaruhi populasi fungi total di rizosfer caisim. Konsorsia mikrob dan kompos hanya meningkatkan jumlah daun sedangkan hasil tidak ditentukan oleh kedua perlakuan.

Kata Kunci: caisim, insektisida organoklorin, kompos, konsorsia mikrob

\section{PENDAHULUAN}

Keberadaan residu insektisida organoklorin yang tergolong Persistant Organic Polutant (POP) masih teridentifikasi meskipun penggunaannya di Indonesia telah dilarang. Senyawa ini sedang dipermasalahkan di dunia akibat sifatnya yang toksik kronis, persisten, dan bioakumulatif (Zhou et al. 2006).

Insektisida organoklorin DDT, aldrin, dieldrin, heptaklor dan endosulfan di Jawa masih ditemukan di lahan-lahan pertanian dengan konsentrasi melebihi ambang batas. Balai Penelitian Lingkungan Pertanian (2007) menemukan residu organoklorin pada tanah dan air di beberapa lahan pertanian kabupaten di Jawa Tengah. Di Kabupaten Demak ditemukan aldrin sebanyak 0,0063 mg $\mathrm{Kg}^{-1}$ dan 0,0010 $\mathrm{mg} \mathrm{Kg}^{-1}$, dieldrin sebanyak 0,004 $\mathrm{mg} \mathrm{Kg}^{-1}$ dan 0,002 $\mathrm{mg} \mathrm{Kg}^{-1}$, dan endosulfan sebanyak 0,0011 mg $\mathrm{Kg}^{-1}$ dan $0,0001 \mathrm{mg} \mathrm{Kg}^{-1}$. Residu insektisida organoklorin di lahan pertanaman sayuran juga perlu dicermati mengingat aplikasi intensif umum dilakukan. Telah dilaporkan keberadaan DDT dalam di lahan sayuran di Provinsi Songkhla Thailand yang terpapar DDT akibat aplikasinya selama 30 tahun, dengan kecenderungan penurunan populasi bakteri di tanah tercemar DDT (Sonkong et al. 2008). Sutrisno et al. (2009) melaporkan bahwa terdapat residu pestisida DDT pada caisim dari Tanah Karo sebanyak 0,006 mg Kg-1 dan dari Dairi sebanyak 0,005 $\mathrm{mg} \mathrm{Kg}^{-1}$. Sampel wortel yang dianalisis menunjukkan bahwa bahan aktif endosulfan juga dominan pada sampel wortel, baik yang diambil dari Malang maupun Cianjur dengan kadar tertinggi 10,6 ppb (Munarso et al. 2006).

Selain dapat menyebabkan penyakit akut dan kronis pada manusia, pestisida golongan POP juga diketahui dapat menurunkan populasi predator dan menurunkan populasi organisme yang berperan penting dalam menjaga kesuburan tanah. Pestisida di dalam tanah berefek langsung terhadap sejumlah aspek mikrobiologis yang selanjutnya akan mempengaruhi pertumbuhan tanaman.
Beberapa efek penting yang disebabkan pestisida adalah perubahan keseimbangan ekologi mikroflora tanah dan perubahan mikroflora tanah. Metil paration dan DDT mereduksi jumlah nodula alfalfa dan hasil tanaman sampai setengahnya (Potera 2007).

Degradasi enzimatis dengan pemanfaatan mikrob sering dianjurkan untuk bioremediasi residu POP. Enam isolat bakteri dapat mendegradasi DDT menjadi 1, 1-dikloro2,2-bis (p-klorofenil) etana (DDD) tetapi tidak ada satu isolat pun yang mendegradasi DDT menjadi 1,1-dikloro-2,2bis(p-klorofenil) etilena (DDE), dan degradasi oleh kultur campuran keenam isolat lebih tinggi $(82,63 \%)$ daripada kultur tunggal yaitu antar 28,48-58,08\% (Mwangi 2010). Fungi Trichoderma harzianum dapat mendegradasi DDT, dieldrin, endosulfan, pentaklorobenzeno, dan pentaklorofenol. Fungi tersebut mendegradasi endosulfan pada berbagai kondisi nustrisi sepanjang fase pertumbuhannya dengan endosulfan sulfat dan endosulfan diol sebagai metabolit utama (Katayama \& Matsumura 2009). Suatu spesies Pseudomonas dapat mendegradasi 1,1,1-trikloro-2,2-bis(4-klorofenil)etana (DDT) dan membentuk senyawa antara 2,3-dihidroksi-DDT dan setelah penghilangan cincinnya menjadi asam 4klorobenzoat yang stabil (Kamanavalli \& Ninnekar 2005). Pada penelitian sebelumnya, pengujian mikrob heterotrof yaitu bakteri Pseudomonas mallei dan jamur Trichoderma sp. koleksi Fakultas Pertanian Unpad menunjukkan bahwa keduanya dapat mendegradasi heptaklor, endosulfan, dieldrin, dan DDT. Pseudomona mallei adalah mikrob pelarut fosfat dan Trichoderma sp. adalah pendekomposer yang juga berperan melarutkan fosfat, yang dapat meningkatkan pertumbuhan tanaman.

Kapasitas degradasi mikrob heterotrof dapat ditingkatkan dengan penambahan bahan organik yang berperan sebagai sumber karbon dan energi mikrob heterotrof. Di lain pihak, penambahan bahan organik akan menguntungkan pertumbuhan tanaman sayuran. Mengingat pentingnya keberadaan mikrob di rizosfer 
tanaman, efek bioremediasi dengan mikroorganisme dan bahan organik terhadap populasi mikrob di rizosfer perlu diteliti sebagai upaya untuk menurunkan konsentrasi POP dan menjaga produksi tanaman sayuran yang banyak dikonsumsi seperti caisim (Brassica juncea L.). Penelitian ini dilakukan untuk mengetahui pengaruh $P$. mallei dan Trichoderma sp. serta kompos terhadap populasi bakteri dan jamur total di rizosfer serta pertumbuhan caisim pada Andisols yang dikontaminasi insektisida organoklorin heptaklor, endosulfan, dieldrin, dan DDT.

\section{BAHAN DAN METODE}

Penelitian ini dilaksanakan di rumah kaca Balai Penelitian Lingkungan Pertanian Jakenan (15 m dpl) Jawa Tengah pada September-November 2011. Persiapan dan penentuan populasi mikrob dilakukan di Laboratorium Biologi dan Bioteknologi Tanah Fakultas Pertanian Unpad. Analisis residu pestisida dilakukan di Balai Penelitian Lingkungan Pertanian Jakenan.

Rancangan penelitian adalah Rancangan Acak Kelompok pola faktorial dengan dua faktor dan tiga ulangan. Faktor pertama adalah inokulasi mikrob yang terdiri atas tanpa dan dengan mikrob konsorsia $P$. mallei dan Trichoderma sp. $\left(\mathrm{m}_{1}\right)$, faktor kedua adalah jenis kompos yang terdiri atas tanpa kompos $\left(\mathrm{p}_{0}\right)$, serta dengan kompos kotoran ayam $\left(\mathrm{p}_{1}\right)$, kotoran sapi $\left(\mathrm{p}_{2}\right)$, dan petroganik $\left(\mathrm{p}_{3}\right)$.

Lapisan olah tanah Andisol asal Pangalengan Kabupaten Bandung (pH 6,4, C-organik 3,1\%, N-organik 0,39\%, $\mathrm{P}_{2} \mathrm{O}_{5}$ tersedia 107,9 mg Kg-1 dan $\mathrm{K}_{2} \mathrm{O}$ tersedia $41 \mathrm{mg}$ $100 \mathrm{~g}^{-1}$ ) dikeringudarakan, disaring dengan saringan $2 \mathrm{~mm}$, dan dimasukkan sebanyak $3 \mathrm{Kg}$ ke dalam setiap polibag. Tanah kemudian dikontaminasi dengan campuran dieldrin, DDT, heptaklor, dan Endosulfan dengan konsentrasi akhir $5 \mathrm{mg} \mathrm{L}^{-1}$ sebanyak $10 \mathrm{~mL}$ per polibag, lalu diinkubasi selama 48 jam. Tanah diaduk rata dengan kompos sebanyak $20 \mathrm{t} \mathrm{ha}^{-1}$ (33,3 g per polibag) untuk kompos kotoran ayam dan kotoran sapi, serta $2 \mathrm{t} \mathrm{ha}^{-1}$ (3,33 g per polibag) untuk kompos petroganik, kemudian diinkubasi selama 24 jam.

Konsorsia mikrob yang terdiri atas $P$. mallei dan Trichoderma sp. koleksi Laboratorium Biologi dan Bioteknologi Tanah Fakultas Pertanian Unpad dipersiapkan dalam bentuk kultur cair masing-masing pada media Nutrient Broth dan Potato Dextrose Broth. Inokulan cair jamur dengan kepadatan $10^{5}$ spora $\mathrm{mL}^{-1}$ dan bakteri dengan kepadatan $10^{7} \mathrm{CFU} \mathrm{mL}^{-1}$ ditambahkan merata ke tanah sebanyak $100 \mathrm{~mL}$ sehingga sel yang ditambahkan ke dalam tanah adalah jamur $10^{7}$ per polibag dan bakteri $10^{9}$ per polibag.

Bibit caisim kultivar toksakan dipindahtanamkan ke tanah di polibag. Pemupukan N, P, dan K dilakukan sesuai dengan rekomendasi, yaitu urea sebanyak $374 \mathrm{Kg} \mathrm{ha}^{-1}$ (0,62 g per polibag), SP-36 sebanyak $311 \mathrm{Kg} \mathrm{ha}^{-1}(0,51 \mathrm{~g}$ per polibag), dan $\mathrm{KCl}$ sebanyak $224 \mathrm{Kg} \mathrm{ha}^{-1}$ (0,37 g per polibag). pemupukan urea dilakukan 2 kali, masing-masing $1 / 2$ dosis pada 7 dan 14 hari setelah tanam (HST) dengan cara. Tanaman dipelihara selama 25 hari, dari 7-21 hari setelah tanah, tinggi tanaman dan jumlah daun diukur seminggu sekali. Di akhir penelitian dilakukan pengukuran populasi bakteri dan jamur di rizosfer dengan metode pelat pengenceran (Schinner 1995) serta bobot segar tajuk. Data populasi mikrob dan bobot segar tajuk dianalisis dengan analisis ragam dengan Uji F pada taraf 5\% dan Uji Jarak Berganda Duncan pada taraf 5\%.

\section{HASIL DAN PEMBAHASAN}

Populasi Mikrob di Rizosfer Caisim. Pengaruh mikrob konsorsia terhadap populasi bakteri ditentukan oleh jenis kompos. Tanpa kompos, aplikasi mikrob tidak mengubah populasi bakteri. Namun dengan pemberian kompos populasi bakteri meningkat kecuali pada perlakuan pupuk kotoran ayam (Tabel 1).

Rendahnya jumlah bakteri pada tanah dengan perlakuan mikrob dan kompos kotoran ayam $\left(\mathrm{m}_{1} \mathrm{~b}_{1}\right)$ dimungkinkan mengingat pada umunya peternak ayam menggunakan antibiotik, sehingga ada peluang residu antibiotik terbawa pada kotoran ayam dan dapat menghambat pertumbuhan bakteri dan aktivitas degradasinya (Antonius 2007). Populasi bakteri tertinggi diperolah dari rizosfer caisim yang ditanam dengan inokulasi mikrob konsorsia dan kompos kotoran sapi $\left(\mathrm{m}_{1} \mathrm{~b}_{2}\right)$, yaitu 4,13 CFU g-1 . Baik inokulasi mikrob maupun aplikasi berbagai jenis kompos tidak berpengaruh terhadap populasi jamur pada rizosfer caisim (Tabel 2) namun meskipun tidak nyata, inokulasi konsorsia mikrob maupun kompos sedikit menurunkan populasi jamur total di rizosfer caisim. 
Tabel 1 Interaksi antara mikrob dengan kompos terhadap populasi bakteri

\begin{tabular}{|c|c|c|c|c|}
\hline \multirow{2}{*}{ Mikrob } & \multicolumn{4}{|c|}{ Kompos } \\
\hline & Tanpa kompos & $\begin{array}{c}\text { Kompos } \\
\text { kotoran ayam }\end{array}$ & $\begin{array}{c}\text { Kompos } \\
\text { kotoran sapi }\end{array}$ & $\begin{array}{c}\text { Kompos } \\
\text { petroganik }\end{array}$ \\
\hline \multicolumn{5}{|c|}{ 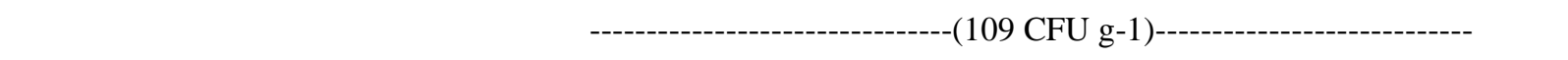 } \\
\hline Tanpa mikrob & $\begin{array}{c}1,40 \mathrm{a} \\
\text { (a) }\end{array}$ & $\begin{array}{l}2,90 \mathrm{a} \\
\text { (b) }\end{array}$ & $\begin{array}{c}2,06 \mathrm{a} \\
(\mathrm{ab})\end{array}$ & $\begin{array}{l}0,93 \mathrm{a} \\
\text { (a) }\end{array}$ \\
\hline Dengan mikrob & $\begin{array}{c}1,86 \mathrm{a} \\
\text { (a) }\end{array}$ & $\begin{array}{l}1,50 \mathrm{a} \\
\text { (a) }\end{array}$ & $\begin{array}{l}4,13 \mathrm{~b} \\
\text { (b) }\end{array}$ & $\begin{array}{l}1,63 \mathrm{a} \\
\text { (a) }\end{array}$ \\
\hline
\end{tabular}

Keterangan : Angka yang ditandai dengan huruf yang sama adalah tidak berbeda nyata menurut uji jarak berganda duncan pada taraf 5\%. Huruf dalam kurung dibaca arah horizontal dan huruf tanpa kurung dibaca arah vertikal

Tabel 2 Pengaruh mikroba dan kompos terhadap populasi jamur di rizosfer

\begin{tabular}{lc}
\hline \multicolumn{1}{c}{ Perlakuan } & $\begin{array}{c}\text { Populasi Jamur } \\
\left(10^{4} \mathrm{CFU} \mathrm{g}^{-1}\right)\end{array}$ \\
\hline Mikrob & \\
Tanpa Mikrob & $4,3 \mathrm{a}$ \\
Mikrob konsorsia & $3,2 \mathrm{a}$ \\
(Bakteri + Jamur) & \\
\hline Kompos (K) & $4,1 \mathrm{a}$ \\
Tanpa kompos & $3,7 \mathrm{a}$ \\
Kompos kotoran ayam & $3,7 \mathrm{a}$ \\
Kompos kotoran sapi & $3,4 \mathrm{a}$ \\
Kompos petroganik & \\
\hline
\end{tabular}

Keterangan : Angka yang ditandai dengan huruf yang sama tidak berbeda nyata menurut uji Duncan pada taraf nyata 0,05 .

Hasil di atas menjelaskan bahwa bakteri dan jamur di rizosfer caisim memberikan respon yang berbeda terhadap inokulasi mikrorb konsorsia dan bahan organik meskipun efek bahan organik telah dibuktikan dapat meningkatkan populasi mikroba rizosfer. Tanpa keberadaan pestisida, Aplikasi farm yard manure, kompos maupun vermicompost meningkatkan populasi bakteri dan jamur dibandingkan kontrol (Das \& Dkhar 2011). Pada penelitian ini, aplikasi insektisida dapat mengubah arah interaksi mikrob-tanaman seperti yang dijelaskan oleh Narasimhan et al. (2003) untuk pestisida organoklorin. Fungisida yang mengandung klorida juga menyebabkan perubahan ukuran komunitas bakteri dan jamur yang dapat disebabkan oleh penghambatan atau penghancuran komponen yang berperan dalam komunitas mikrob tanah (Sigler \& Turco 2002).
Sinergisme antara Pseudomonas dan Trichoderma eksogen dan kompos untuk meningkatkan populasi bakteri memperlihatkan bahwa komponen pendukung interaksi tetap bertahan di dalam lingkungan tanah dengan organoklorin. Sangat mungkin bakteri juga mengonsumsi organoklorin sebagai sumber karbon. Tidak ada efek kedua perlakuan terhadap populasi jamur disebabkan oleh perubahan struktur mikrob yang memicu kompetisi nutrisi, dan penurunan viabilitas dan kemampuan proliferasi jamur rizosfer di tanah dikontaminasi pestisida organoklorin. Namun pendapat yang terakhir perlu dibuktikan oleh penelitian lainnya karena pada penelitian ini tidak ada perlakuan kontrol berupa tanah tidak dikontaminasi. Pemberian kompos tidak mempengaruhi populasi jamur, juga dapat disebabkan karena $\mathrm{pH}$ tanah Andisol di akhir percobaan mencapai 6,4. Semakin meningkat $\mathrm{pH}$ tanah maka jumlah jamur di tanah semakin menurun (Lubis 2010).

Pertumbuhan dan Hasil Tanaman. Menurut deskripsi tanaman caisim kultivar Toksakan, saat panen tinggi tanaman akan mencapai timggi 30-70 cm. Pada 21 HST, tinggi tanaman tajuk berdasarkan pengukuran adalah antara 35-39 cm. Analisis statistik memperlihatkan bahwa pengaruh perlakuan mikrob terhadap tinggi tanaman tidak dipengaruhi oleh taraf kompos manapun, dan baik mikrob maupun kompos tidak mempengaruhi tinggi tanaman. Berdasarkan perhitungan statistik, tinggi tanaman yang diberi kompos adalah 37,1-37,9 cm, sama dengan tinggi tanaman kontrol $37,7 \mathrm{~cm}$. Pemberian bioremediator konsorsia Pseudomonas dan Trichoderma dapat meningkatkan tinggi tanaman sampai 38,5 cm dibandingkan 
Tabel 3 Pengaruh interaksi antara inokulasi mikroba konsorsia dan kompos terhadap jumlah daun caisim pada umur 21 hari setelah tanam

\begin{tabular}{lcccc}
\hline Perlakuan & Tanpa kompos & $\begin{array}{c}\text { Kompos } \\
\text { kotoran ayam }\end{array}$ & $\begin{array}{c}\text { Kompos } \\
\text { kotoran sapi }\end{array}$ & $\begin{array}{c}\text { Kompos } \\
\text { petroganik }\end{array}$ \\
\hline Tanpa Mikrob & $12,67 \mathrm{a}$ & $15,33 \mathrm{a}$ & $17,33 \mathrm{a}$ & $14,33 \mathrm{a}$ \\
(a) & $(\mathrm{a})$ & $(\mathrm{ab})$ & $(\mathrm{b})$ & $(\mathrm{ab})$ \\
Dengan Mikrob & $15,67 \mathrm{~b}$ & $15,67 \mathrm{a}$ & (a) & $16,67 \mathrm{~b}$ \\
& (a) & (a) & (a) & \\
\hline
\end{tabular}

Keterangan: Angka yang ditandai dengan huruf yang sama adalah tidak berbeda nyata menurut uji jarak berganda duncan pada taraf $5 \%$. Huruf dalam kurung dibaca arah horizontal dan huruf tanpa kurung dibaca arah vertikal

Tabel 4 Pengaruh mikrob dan kompos terhadap bobot basah tajuk tanaman caisim

\begin{tabular}{lr}
\hline \multicolumn{1}{c}{ Perlakuan } & $\begin{array}{c}\text { Bobot basah tajuk } \\
\text { caisim }\end{array}$ \\
\hline Mikrob (M) & $169,5 \mathrm{a}$ \\
$\mathrm{m}_{0}=$ Tanpa Mikrob & $169,0 \mathrm{a}$ \\
$\mathrm{m}_{1}=$ Mikrob konsorsia & \\
(Bakteri + Jamur) & $155,9 \mathrm{ab}$ \\
Kompos (K) & $178,9 \mathrm{~b}$ \\
$\mathrm{~b}_{0}=$ Tanpa kompos & $177,0 \mathrm{~b}$ \\
$\mathrm{~b}_{1}=$ Kompos kotoran ayam & $165,2 \mathrm{ab}$ \\
$\mathrm{b}_{2}=$ Kompos kotoran sapi & \\
$\mathrm{b}_{3}=$ Kompos petroganik &
\end{tabular}

Keterangan: Angka yang ditandai dengan huruf yang sama tidak berbeda nyata menurut uji Duncan pada taraf nyata 0,05 .

dengan kontrol $36,5 \mathrm{~cm}$ tetapi tidak berbeda nyata secara statistik.

Jumlah helai daun baik yang sudah maupun belum terbuka sempurna pada umur 0-7 HST relatif seragam di tiap perlakuan yaitu 5-7 helai. Pada 21 HST jumlah daun bertambah mencapai rata-rata 15 helai dan terdapat sinergitas yang nyata antara mikrob bioremediator dengan pupuk organik pada peningkatan jumlah daun (Tabel 3). Jumlah daun terkecil (12,67 helai), terdapat pada tanaman tanpa mikrob konsorsia dan tanpa kompos sedangkan jumlah daun terbesar (16,67 helai), dihasilkan oleh tanaman dengan mikrob dan dengan kompos petroganik $\left(\mathrm{m}_{1} \mathrm{~b}_{3}\right)$.

Tidak ada interaksi antara mikrob dan bahan organik terhadap hasil tanaman caisim, dan hanya perlakuan kompos yang berperan terhadap peningkatan bobot basah tajuk caisim. Bobot tajuk caisim tertinggi diperoleh dari tanaman yang diberi perlakuan kompos kotoran ayam $(178,9 \mathrm{~g})$ dan kompos kotoran sapi (177,0 g), namun secara statistik perbedaan ini tidak terlalu nyata jika dibandingkan dengan kedua perlakuan lainnya (Tabel 4) Bobot segar per tanaman lebih rendah daripada yang seharusnya, $400 \mathrm{~g}$ menurut deskripsi caisim kultivar Toksakan yang dikeluarkan oleh PT. East West Seed (2006).

Percobaan ini dilakukan di rumah kaca dengan suhu rata-rata pada siang hari mencapai $43^{\circ} \mathrm{C}$, tanah sering berada dalam keadaan relatif kering yang membatasi siklus nutrisi oleh tanaman, serta ketersediaan dan serapannya.

P. mallei dan Trichoderma sp. yang digunakan pada penelitian ini adalah bakteri pelarut fosfat. Tidak meningkatnya hasil tanaman setelah inokulasi kedua mikroba karena bakteri dan jamur tersebut telah diinduksi di dalam beberapa konsentrasi heptaklor, dieldrin, endosulfan, dan DDT sehingga kapasitasnya sebagai biofertilizer maupun bioprotectant dapat menurun.

Ketiadaan efek kompos dan rendahnya bobot segar ini dapat disebabkan oleh adanya insektisida organoklorin dalam konsentrasi yang tinggi. Dugaan ini berkaitan dengan kemungkinan insektisida yang ditambahkan belum terdegradasi sampai di bawah konsentrasi yang tidak meracuni. Meskipun inokulasi dilakukan tetapi kondisi yang mendukung biodegradasi tidak optimal seperti yang dijelaskan Frazar (2000) mengenai persistensi pestisida.

\section{SIMPULAN}

Pengaruh konsorsia P. mallei dan Trichoderma sp. terhadap populasi bakteri total tanah ditentukan oleh jenis kompos. Pemberian mikrob dan kompos kotoran sapi memberikan populasi bakteri rizosfer terbaik yaitu $4,13 \times 10^{9} \mathrm{CFU} \mathrm{g}^{-1}$ dibandingkan dengan perlakuan lainnya. Baik aplikasi mikrob maupun kompos tidak mempengaruhi populasi jamur total di rizosfer caisim. Pada pengukuran komponen pertumbuhan, aplikasi kedua perlakuan tidak berpengaruh terhadap tinggi tanaman tetapi meningkatkan jumlah daun. Meskipun kompos kotoran ayam dan kotoran 
sapi menghasilkan bobot basah tajuk sebesar masingmasing 178,9 g dan 177,0 g, tertinggi dibandingkan dengan perlakuan kompos lainnya, namun tidak signifikan secara statistik.

\section{DAFTAR PUSTAKA}

Das, B.B \& Dkhar, M.S. 2011. Rhizosphere microbial populations and physico chemical properties as affected by organic and inorganic farming practices. American-Eurasian J. Agric. \& Environ. Sci 10(2): 140-150.

East West Seed Indonesia. 2006. Deskripsi beberapa varietas caisim. Purwakarta: PT. East West Seed Indonesia.

Frazar, C. 2000. The Bioremediation and Phytoremediation of Pesticide-contaminated Sites. Washington, DC: U.S. Environmental Protection Agency,.

Kamanavalli, C.M \& Ninnekar, H.Z. 2000. Biodegradation of DDT by a pseudomonas species. Current Microbiology 48(1): 10-13.

Katayama, A \& Matsumura, F. 2009. Degradation of organochlorine pesticides, particularly endosulfan byTrichoderma harzianum. Environmental Toxicology and Chemistry 12(6): 1059-1065.

Lubis, S. 2008. Dinamika Populasi Jamur pada Tanah Ultisol Akibat Pemberian Berbagai Bahan Organik Limbah Perkebunan. Skripsi Jurusan Ilmu Tanah dan Sumberdaya Lahan. Fakultas Pertanian. Medan: Universitas Sumatera Utara.
Mwangi, K., Boga, H.I., Muigai, A.W., Kiiyukia, C \& Tsanuo, M.K. 2010. Degradation of dichlorodiphenyltrichloroethane (DDT) by bacterial isolates from cultivated and uncultivated soil. African Journal of Microbiology Research 4(3): 185-196.

Munarso, S.J., Miskiyah, \& Wisnu Broto. 2006. Studi kandungan residu pestisida pada kubis, tomat, dan wortel di Malang dan Cianjur. Buletin Teknologi Pascapanen Pertanian 2: 27-32.

Narasimhan, K., Basheer, C \& Swarup, S. 2003. Enhancement of plant-microbe interaction using a rhizosphere matabolomics-driven approach and Its Application in the Removal of Polychlorinated Biphenyls. Plant Physiol 132(1): 146-153.

Poteria, C. 2007. Agriculture: Pesticides Disrupt Nitrogen Fixation. Environ Health Perspect. Environews: 115(12): A579.PMCID: PMC2137115.

Sigler, W.V \& Turco, R.F. 2002. The impact of chlorothalonil application on soil bacterial and fungal populations as assessed by denaturing gradient gel electrophoresis. Appl. Soil Ecol 21: 107-118.

Sonkong, K., Prasertsan, P \& Sobhon, V. Screening and identification of $p, p \phi-D D T$ degrading soil isolates. Songklanakarin J. Sci. Technol 30(1): 103-110.

Zhou, R., Zhu, L., Yang, K \& Chen, Y. 2006. Distribution of Organochlorine Pesticides in Surface Water and Sediments from Qiantang River, East China. Journal of Hazardous Materials 137(1): 68-75. 